\title{
A Case Study of Students with Visual Disabilities in Inclusive Higher Education
}

\author{
Mayasari Manar, Endang Rochyadi, Sunardi \\ Indonesia University of Education \\ Bandung, Indonesia \\ manarmaya@ymail.com
}

\begin{abstract}
Inclusive higher education provides opportunities for various barriers related to services provided for students with visual disabilities. This study aimed to provide an understanding of the needs of students with visual disabilities in universities and solutions to meet the needs of these students. The method adopted in the study was qualitative using case study design. The participants were three of students with visual disabilities in a college, consisting of one student with totally blind and two of students of low vision. The data were collected by observations on two settings, in class and outside class, lectures and in-depth interviews with several lecturers and students with visual disabilities. The finding of this study indicated that there are several needs of students with visual disabilities that have not been fully accommodated by institution, namely assessment services before learning process, orientation and mobility services to provide support services for students with visual disabilities and access to learning sources. The solutions offered to meet the needs of students with visual disabilities in college are providing an assessment service before starting the learning process, the availability of orientation and mobility services at the beginning of the semester, and the availability of learning resources that access for these students.
\end{abstract}

Keywords—students with visual disabilities; inclusive higher education.

\section{INTRODUCTION}

Inclusive higher education supports policies to obtain equal rights for people with disabilities in universities [1]. This is supported by the number of students with disabilities which are increasing in accordance with the reports of Reference [2], in $2014 / 2015$ that showed $5.1 \%$ of the total population of individuals with disabilities was in college. This prevalence certainly has implications for education services provided by universities for students with disabilities so that universities provide an environment that can support the educational process for students with disabilities. In addition, the state of the higher education environment should accommodate the needs and diversity of each individual needs in order to develop inclusive education [3]. One of the government's efforts to meet the educational needs of individuals with disabilities in universities is the issuance of Law No. 46 of 2017 concerning Special Education and Special Service Education in Higher Education [4]. Law No. 8 of 2016 Article 10 concerning the right to education of persons with disabilities. The policy requires universities to provide friendly education services for students with disabilities.

Inclusive education not only places people with disabilities into the regular learning environment or includes as many people with disabilities as possible to the regular learning environment without planning, support, or learning resources [5], [6]. Inclusive education seeks to ensure equal rights in obtaining educational needs for students with disabilities, ensure the individuals to be able to learn together regardless of individual barriers or differences as long as possible, recognize and respond to diverse individual needs, accommodate various styles and speed of learning, and ensure education quality by paying attention to the right curriculum design, and utilization of learning resources and learning strategies [7].

One group of people with disabilities who still experiences difficulties in accessing education services at universities is students with visual disabilities. Educational services for students with visual disabilities have not been fully accommodated by universities, related to learning needs both in the classroom and outside the classroom. Without special support, these students experience difficulties in achieving a brilliant academic career [8]. While ideally, students with visual disabilities need services that are different from other students, including personal support, both in terms of ways, tools, support while reading and mobility around the university so that learning activities run effectively and efficiently[4], [9]. The condition of educational services for students with visual disabilities in universities has an impact on student performance in obtaining academic quality, while the number of students with visual disabilities per year has increased.

Reporting from UCAS (Universities and Colleges Admissions Service) noted the number of students with visual disabilities who enrolled in undergraduate programs in universities with totally blind and low vision proportions between 2009 and 2014, which were from $0.16 \%$ and 895 to $0.11 \%$ and 610 . While data from the higher education statistics agency reported there were 1,040 students with visual disabilities at various levels and study programs in the 20132014 academic year [10]. The latest data from PERTUNI (Indonesian Blind Union) reported that the number of people with visual disabilities who have attended tertiary education has increased by 30 percent in 2015 as many as 250 people and the latest data was around 400 people (nasional.republika.co.id) 


\section{LITERATURE REVIEW}

Inclusive education is a movement that seeks to overcome various obstacles related to the social environment, particularly in the teaching and learning process [11]. In accordance with the Reference [12], Framework for Action, the basic principle of inclusive education is that every individual has equal opportunities to learn together regardless of the difficulties encountered or differences. Several legal documents that underlie the implementation of education for individuals with disabilities according to the Reference [13], namely: (a) the Universal Declaration of Human Rights 1948 (Declaration of Human Rights), (b) World Declaration on Education for All Education Jomtien, Thailand, 1990, (c) Revelation of Salamanca (UNESCO), Spayol, 1994, (d) Law Number 19 of 2011 concerning Ratification of the Convention on the Rights of Persons with Disabilities, and (e) National Education Minister's Regulation Number 70 of 2009 concerning Inclusive Education for Students Who Have Abnormalities and Have Potential Intelligence and /or Special Talents.

According to reference [7] inclusive education in higher education provides equal opportunities for all people to be fully involved in learning activities. Inclusive means accommodating the special needs of students with disabilities so that all students have equal opportunities in academic achievement. The development of an inclusive paradigm in learning seeks to appreciate diversity that involves various changes in the learning process, classroom order, and social interactions in the learning environment (Booth and Ainscow, 2002). Learning services should be able to accommodate the learning needs of each student. Special learning and support accommodation is provided according to the learning needs of students with visual disabilities so that the inclusive approach becomes an option in realizing the implementation of education for all [8].

The implementation of inclusive education is an approach that recognizes the diversity of students so that all students are able to access the content of learning and fully participate in learning activities. Learning in an inclusive setting provides meaningful learning, relevant, and accessible to all, including individual differences as a source of diversity that can enrich learning outcomes. Some principles of inclusive learning, namely learning enriched with diverse student experiences, accessible learning for all students and relevant, and students have full access to learning and teaching so that the potential of these students continues to increase [14]

Students with visual disabilities are students who have obstacles in vision, both totally blind and low vision. The student's vision has limitations in the sense of sight so the learning process emphasizes the other sense, namely the sense of touch and the sense of hearing. One of the principles that need to be applied in teaching students with visual impairment is that the media used must be tactual and sound, for example the use of Braille writing, embossed images, model objects, and real objects [15]. Students with disabilities have the same rights in obtaining access to education in universities. The learning environment should be more accessible for all students.

\section{METHOD}

This research was a qualitative research with a case study that describes real conditions of students with visual disabilities in college. Reference [16] defines qualitative research as research that aims to understand the phenomenon of what is experienced by the subject of research, such as behavior, perception, motivation, action as a whole by means of descriptions in the form of words and language in a special context that occurs naturally by utilizing various scientific methods. The selected college is one of the state universities in West Java Province, as one of the universities providing inclusive education. Sample in this study consisted of two parts, which were students with visual disabilities and three lecturers who had experience in teaching students with visual disabilities. The three students consisted of two students with low vision and one student with totally blind. The data collection process was carried out with long-term participant observation in two settings, namely in the lecture class and outside the lecture class. While the interviews were conducted in depth to the three students with visual disabilities and the three lecturers who had experience in teaching students with visual disabilities.

Observations were conducted by observing and recording all the phenomena shown by students with disabilities in the university environment during the observation period. Phenomenon found would be limited by time and various activities, and researchers would collect complete data by using information gathering procedures in accordance with a predetermined time. There were four themes in collecting the data; learning accommodation, barriers to learning, learning support and learning needs. Next, the researcher analyzed the data related to the data obtained in the field. Bogdan \& Biklen stated that qualitative data analysis is an effort carried out through working with data, organizing data, sorting into units that can be managed, synthesizing them, finding skills, and deciding what can be presented to other individuals [17]. Analysis is an attempt to describe a thing into parts so that the composition of the form of something is deciphered clearly [17]. Analysis of the data from interviews was done by reducing the results of the interview data with coding according to the questions, and then presented in a narrative while the data analysis was the result of field observations in order to strengthen the interview data. The activities that became the case in this study were presented in narrative form on the final results of interviews and observations in the form of field notes.

\section{RESULT AND DISCUSSION}

This study aimed to describe the real conditions of students with visual disabilities in college. The learning process for students with visual disabilities in general has not been able to accommodate the needs of individual students, due to the lack of an assessment process. Assessment services for students with visual disabilities have not been used as a basis for providing educational services that are appropriate with student needs. Informally, the assessment process has been carried out by several lecturers related to the ability of students with visual disabilities. While some other lecturers admitted that there were no assessments for students with visual disabilities so the 
lecturers did not know the educational needs that should be given to the students. The lecturers did not change the way of teaching that could accommodate the needs of students with visual disabilities [18]. Assessment is the main point in providing learning services for students with visual disabilities [10]. Without assessment services, the needs of students with visual disabilities are difficult to accommodate.

Another issue experienced by students with visual disabilities was in terms of orientation and mobility. The process of class moving with inadequate infrastructure results in the difficulty of students doing mobility. Infrastructure has not fully accommodated the needs of students with visual disabilities and provided challenges in mobility. Totally blind students were not yet fully capable of being independent towards the lecture room which is in a different building so they must depend on the others. The condition of infrastructure that was less friendly to the needs of students with visual disabilities has an impact on the students' freedom to mobilize in the surrounding university. Various obstacles faced related to the physical condition of the university environment in form of multi-story buildings that are quite complex with a circular staircase situation, an irregular environment triggers the difficulty of students with disabilities to move around the campus. One of the difficulties experienced by students with disabilities is infrastructure constraints [19]. Whereas the two low vision students were able to be independent towards the lecture class, but the students admitted that in certain conditions they still lost their direction towards the lecture hall. Regarding other buildings, in addition to lecture halls, students have not been able to go to other buildings independently, such as a library or university canteen building.

Physical accessibility in meeting the mobilization needs of students with disabilities has not been fully implemented in university life so students still experienced difficulties in accessing infrastructure in the campus environment. In addition, lack of infrastructure conditions and access to learning resources is an obstacle that must be faced by students with visual disabilities. Students experienced difficulties in accessing learning materials, such as inaccessible electronic files, inadequate equipment and lack of time [10], [18]. The availability of learning resources, such as books are not fully accessible to students so students must struggle independently to obtain learning resources that can accommodate the needs of students. Some lecturers acknowledged the difficulty of providing learning materials that could be accessed by students with disabilities even though basically the lecturers realized that the learning resources used so far are not friendly to students with visual disabilities. Limitations of learning resources have implications for the effectiveness of learning received by students with visual disabilities which ultimately affect the academic performance of students. The availability of braille materials in learning materials is still very limited and the soft files provided by the lecturers have not been fully able to accommodate the needs of students. Ideally, special support plays an important role in supporting students with visual disabilities in universities, such as providing braille, audio materials, and other adjustments. Without this support, students will find it difficult to achieve an optimal academic career [8]. The lecturer also admitted that he was not fully able to provide learning material in a form that could be accessed by students with visual disabilities.

Proactive approaches and strategies in inclusive higher education plans not only build a more inclusive culture, but also build individual potential within it. This education ensures that all students have equal opportunities to have flexible teaching, assessment and services to serve different needs [20]. One of the things that distinguishes inclusive learning and not inclusive learning is assessment process carried out before the learning process. The presentation of research findings shows that the learning process for students with visual disabilities in general has not been able to accommodate the needs of individual students, due to the lack of an assessment process. While the assessment according to Salvia and Ysseldyke, is a complex process that encompasses three main aspects which are the previous conditions underlying adaptive behavior, special characteristics, and consequences that will be received after the assessment is carried out so that the assessment results will show student profiles regarding learning needs, learning barriers, and the potential that needs to be developed. Hence, it can be adapted to the methods, materials and strategies used in teaching students with disabilities. Assessment services for students with visual disabilities should be provided by the university in order to accommodate the educational needs of the students and to ensure equal rights in participating in a fair and equal education process.

Furthermore, the unavailability of assessment services for students with visual disabilities, orientation and mobility services for students with disabilities have not been fully accommodated by the university. Meanwhile, basically, the orientation and mobility process is a need for individuals with disabilities to move independently and comfortably in the surrounding environment [21]. The inadequate state of university facilities for people with visual disabilities results in the difficulty of going to lecture classes independently so that they need peer assistance to walk from one place to another, even though there are basically students who prefer to do it by themselves, especially low vision students. Most students with visual disabilities desired orientation and mobility training before starting educational activities in the university environment [10], but these services have not been provided by the university while one of the services that should be provided to students with visual disabilities is orientation services and mobility [7].

Besides, access to learning material is an important part of college life. Students with disabilities generally experience difficulties in accessing learning materials. Related to the support of learning resources, this learning process is also determined by the level of disability that is owned, the skills of braille, the availability of braille materials, the availability of alternative formats such as tactile models, the availability of human assistance, readers / scribes [22]. Accommodation tests such as human support, such as recording, sign language translators, reading and writing interpreters, and even assistants in experimental activities. In addition, institutions also provide class accommodation, for example various digital alternative formats of textbooks, braille displays, screen reader soft software, sound soft devices, classroom recording permits, verbal / written instructions. Other accommodations take the 
form of additional time in tests and examinations, different test locations and accessibility of the physical environment [23].

In accordance with Reference [4], the arrangement of the physical environment in universities must provide various tools / objects that can provide convenience, comfort and security for students with disabilities. Ideally, lecturers should have the knowledge and skills in adapting learning materials and learning methods that are in accordance with the needs and skilled in implementing strategies in classroom management so as not to question the existence of students with disabilities in the classroom. The lack of availability of adaptive learning resources reduces the effectiveness of classroom learning. Reference [10] suggested that these barriers could be overcome by participating in inclusive teaching training, such as making instructional materials through electronics and making adjustments, such as the availability of readers or minutes. In inclusive learning, learning resources must be easily obtained by all students, so that one of the principles of Universal Design Instruction (UDI) is to minimize business for students with visual disabilities in obtaining information.

\section{CONCLUSION}

This study revealed some of the needs of students with visual disabilities that have not been fully accommodated by the tertiary institutions, namely assessment services before starting the learning process, orientation and mobility services, and accessing learning resources. The solutions offered to meet the needs of students with visual disabilities are the availability of assessment services before starting the learning process, the availability of orientation and mobility services at the beginning of the semester, and the availability of learning resources that access for these students.

\section{REFERENCES}

[1] I. Irwanto, E. R. Kasim, A. Fransiska, M. Lusli, and O. Siradj, Analisis Situasi Penyandang Disabilitas di Indonesia: Sebuah Desk-Review. Jakarta: AusAID, 2010.

[2] AHEAD (Association for Higher Education Access and Disability), Numbers of Students with Disabilities Studying in Higher Education in Ireland 2014/15. Huntersville, NC: AHEAD Educational Press, 2016

[3] C. Barnes, "Some thoughts on an Inclusive Higher Education System," in Oral Presentation at Developing and Embedding Inclusion, Brimingham, 2007.

[4] Kemenristekdikti. (2017). Panduan Layanan Mahasiswa Disabilitas di Perguran Tinggi. [Online]. Available: http://belmawa.ristekdikti.go.id/

[5] M. Mudjito, H. Harizal, and E. Elfindri, Pendidikan Inklusif. Jakarta: Baduose Media Jakarta, 2012.

[6] Sapon, Mara, and Shevin, Widening The Circle. USA: Beacon Press Books, 2007.
[7] D. Tarsidi, "Implementation of inclusive education in indonesia a persons with disabilities," Presented at The 8th International Congress on Including Children with Disabilities in the Community Stavanger, Norway, June 15-17, 2004.

[8] M. E Wong, "Support for students with visual impairment in higher eudcation in Singapore: Considering university publicity materials conveying disability sevices and support," Centre for Advancement in Inclusive and Special Education (CAISE), Faculty of Education, The University of Hong Kong. CAISE Review, vol. 2, pp. 62-67, 2014.

[9] France. United Nations Educational, Scientific and Cultural Organization. Provision for Students with Disabilities in Higher Education: A Survey. Paris: UNESCO, 1999.

[10] R. Hewett, S. Keil, and G. Douglas, Experiences of Blind and Partially Sighted Young People as They Make the Transtiton into Higher Education. Birmingharm: Visual Impairment Centre for Teaching and Research (VICTAR), The Department of Disability Inclusion and Special Needs School of Education, University of Birmingham, 2015.

[11] S. Stubbs, Inclusive Education Where There Are Few Resources. Norway: The Atlas Alliance Schweigaardsgt, 2008.

[12] Spain. The Salamanca Statement and Framework for Action on Special Needs Education. Salamanca: UNESCO and Ministry of Education and Science, 1994.

[13] Republik Indonesia. Direktorat Pembinaan Pendidikan Khusus dan Layanan Khusus, Pendidikan Dasar, Strategis Umum Pembudayaan Pendidikan Inklusif di Indonesia. Jakarta: Direktorat Pembinaan PKLK Pendidikan Dasar, 2013.

[14] LTEO, Inclusive Education Briefing: Large Lectures. Bath: University of Bath, 2016.

[15] M. Friend, Special Education: Contemporery Perspectives for School Professionals, 4th ed. United States America: Pearson 2013.

[16] L. J. Moleong, Metodologi Penelitian Kualitatif Edisi Revisi. Bandung: PT Remaja Rosdakarya, 2007.

[17] D. Satori, and A. Komariah, Metodologi Penelitian Kualitatif. Bandung: Alfabeta, 2014.

[18] N. J. Ball, "The Experiences of Severely Visually Impaired Students in Higher Music Education," in Research Seminar, Sibelius Academy, University of the Arts Helsinki, 2017.

[19] O. Andrew, "The Challenges of educating the visually impaired and quality assurance in tertiary institutions of learning in Nigeria," International Journal of Educational Administration and policy Studies. Department of Educational Psychology, Kogi State College of Education, vol. 7, no. 7, pp. 129-133, Sept. 2015.

[20] G. Layer, Inclusive Learning and Teaching at Higher Education As a Route to Excellence. UK: Deopartment for Education, 2017.

[21] L. Agesa, "Challange Faced by Learners with Visual Impairment in Inclusive Setting in Trans-Nzoia County," Journal of Education and Practice, vol.5, no.29, pp. 185-192, 2014.

[22] S. Sahasrabudhe, and P. Palvia, "Academic Challenges of Blind Students and Their Mitigation Strategies Research-in-Progress," in Proceedings of the Nineteenth Americas Conference on Information Systems, Chicago, Illinois, 2013, pp. 1-10.

[23] T. Kondo, and S. Shirasawa, "Recent Progress and Future Challenges in Disability Student Services in Japan," Journal of Postsecondary Education and Disability, vol. 28, no. 4, pp. 421-431, 2016. 